\title{
Public Opinion Quarterly
}

Journal of the American Association for Public Opinion Research

\section{AAPOR Advisory Committee}

Chair: Robert Y. Shapiro, Columbia University (2014-2018)

Frederick G. Conrad, University of Michigan (2015-2018)

D. Sunshine Hillygus, Duke University (2016-2018)

Joe Lenski, Edison Research (2014-2016)

Rich Morin, Pew Research Center (2015-2017)

\section{Editors}

Patricia Moy, University of Washington

Tom W. Smith, NORC at the University of Chicago

\section{Managing Editor}

Phyllis Silverstein, University of Washington

\section{Associate Editors}

Eric Plutzer, Pennsylvania State University

\section{Section Editors}

Poll Reviews

Michael W. Traugott, University of Michigan

Christopher Wlezien, University of Texas at Austin

Poll Trends

Greg M. Shaw, Illinois Wesleyan University

Book Reviews

Travis N. Ridout, Washington State University

\section{Editorial Board}

Scott L. Althaus, University of Illinois

Stephen D. Ansolabehere, Harvard University

Paul C. Beatty, National Center for Health Statistics

Janet M. Box-Steffensmeier, The Ohio State University

Paul R. Brewer, University of Delaware

J. Michael Brick, Westat

Frederick G. Conrad, University of Michigan

Darren Davis, Notre Dame University

Michael X. Delli Carpini, University of

Pennsylvania

Wil Dijkstra, Free University

Don A. Dillman, Washington State University

James N. Druckman, Northwestern University

Jennifer Dykema, University of

Wisconsin-Madison

Marc N. Elliott, The RAND Corporation

Michael R. Elliott, University of Michigan

Robert S. Erikson, Columbia University

Craig A. Hill, RTI International

D. Sunshine Hillygus, Duke University
Allyson Holbrook, University of Illinois at Chicago

Simon Jackman, Stanford University

Scott Keeter, Pew Research Center

John M. Kennedy, Indiana University

Kate Kenski, University of Arizona

Neil Malhotra, Stanford University

Daniel M. Merkle, ABC News

Peter V. Miller, U.S. Bureau of the Census

Diana C. Mutz, University of Pennsylvania

Lance J. Rips, Northwestern University

Robert Santos, The Urban Institute

Nora Cate Schaeffer, University of Wisconsin-Madison

Robert Y. Shapiro, Columbia University

Tamir Sheafer, Hebrew University

Eleanor Singer, University of Michigan

Mark A. Tessler, University of Michigan

David Tewksbury, University of Illinois

Claes H. de Vreese, University of Amsterdam

Gordon Willis, National Cancer Institute, National Institutes of Health

David C. Wilson, University of Delaware

Cliff Zukin, Rutgers University

Editorial Office University of Washington, Department of Communication Box 353740, Seattle, WA 98195-3740 (email: poq@uw.edu)

AAPOR One Parkview Plaza, Suite 800, Oakbrook Terrace, IL 60181 (www.aapor.org) 